\title{
Effect of a Grain Refiner Cum Modifier on Mechanical Properties of Al-7Si and Al-11Si Alloys
}

\author{
S. M. Jigajinni ${ }^{1}$, K. Venkateswarlu ${ }^{2, *}$, and S. A. Kori ${ }^{1, \uparrow}$ \\ ${ }^{1} \mathrm{R} \&$ D Centre, Department of Mechanical Engineering, Basaveshwar Engineering College, \\ Bagalkot-587 102, India \\ ${ }^{2}$ CSIR-National Aerospace Laboratories, Bangalore-560 017, India \\ ${ }^{\dagger}$ Currently, Visvesvaraya Technological University, Belgaum-590 018, India
}

(received date: 1 September 2011 / accepted date: 2 May 2012)

\begin{abstract}
This study evaluates the influence of grain refiners/modifiers on the mechanical properties of the Al-7Si and Al-11Si alloys with an experiment of quantitative and qualitative correlations with the microstructure. Modification of Al-Si alloys with strontium additions and grain refinement with Al-Ti, Al-B and Al-T-B master alloy additions are demonstrated to be efficient on Al-Si alloys. A single master alloy with combined additions of $\mathrm{Sr}$ and $\mathrm{Ti}$ and/or B was prepared and the microstructure and mechanical properties were studied. The results show that boron rich (Al-3B-Sr and Al-1Ti-3B-Sr) master alloys are more efficient than $\mathrm{Ti}$ rich (Al-3Ti-Sr and Al-5Ti-1B-Sr) master alloys considering their combined grain refinement and modification effect on Al-7Si and Al-11Si alloys. However, the presence of $\mathrm{Sr}$ does not influence the grain refinement. Similarly, presence of grain refiner does not influence the modification of eutectic Si.
\end{abstract}

Key words: alloys, casting, grain refinement, scanning electron microscopy, dendritic arm spacing

\section{INTRODUCTION}

The outstanding effect of adding silicon as a major alloying element to aluminum results in excellent castability, good corrosion resistance, and hot tear resistance, together with improved machinability and weldability. However, binary Al-Si alloys with hypoeutectic and eutectic compositions are generally characterized in terms of corrosion resistance and good castability as silicon increases the fluidity of the molten aluminum. Additionally they reduce the melting temperature. Being a low-density material $\left(2.7 \mathrm{~g} / \mathrm{cm}^{3}\right)$, the overall weight of the final component of the Al-Si alloy is reduced. Application of binary Al-Si alloys varies from domestic food components to automotive and aircraft parts, some of which include cylinder heads and intake manifolds to achieve greater weight reduction [1-3]. However, eutectic silicon in an untreated hypoeutectic Al-7Si alloy forms a brittle coarse acicular or plate type material with sharp edge shaped silicon particles and these particles act as notches or internal stress points that set internal stresses in the final microstructure. These stresses find an easy path for fracture that drastically reduces the tensile properties, especially elongation or ductility. Hence, eutectic silicon in the Al-Si

*Corresponding author: karodi2002@yahoo.co.in

CKIM and Springer, Published 10 March 2013 alloy is modified into a fine rounded globular phase that improves ductility. Sodium, antimony and strontium are used as modifiers for modification of eutectic silicon [1,4]. Compared to $\mathrm{Na}$, Sr has the advantage of long lasting (up to two hours of incubation time) and high reproducible recoveries, even though a fine fibrous microstructure can also be obtained from Na. Uzun et al. [5] have shown that the addition of $0.50 \mathrm{wt} \%$ of antimony (Sb) to Al-12Si alloy is sufficient to obtain a fine microstructure that consists of fibrous Si particles. Antimony also modifies the eutectic silicon from needle form into a fine fibrous form but has the drawback of liberation of Stibibe $\left(\mathrm{SbH}_{3}\right)$ which is toxic in nature $[2,6]$. Strontium on the other hand will not pose any health problems and hence in this study, $\mathrm{Sr}$ in the form of an $\mathrm{Al}-10 \mathrm{Sr}$ master alloy is used. This addition dramatically changes the plate-like or lamellar eutectic silicon particles into a fine distribution of fibrous silicon particles and disperses the porosity as it modifies the eutectic structure, thereby leading to improvement in mechanical properties [2,3,6-10].

The near to eutectic Al-Si alloy composition, i.e., the Al$11 \mathrm{Si}$ alloy consists of a small number of star shaped primary silicon phases in addition to a plate-like eutectic silicon phase and these primary silicon particles are usually very coarse and impart inferior mechanical and tribological properties. Such alloys require limited attention for use because of the presence of the extremely hard primary silicon phase 
that reduces the life of the tool during machining. Proper control over the microstructure is achieved by the addition of an $\mathrm{Al}-10 \mathrm{Sr}$ master alloy to the near eutectic Al-Si melt, thereby coarsening the primary silicon, and elongated eutectic silicon particles occur simultaneously $[3,8,11,12]$.

The Al-Si alloy in the untreated condition also consists of a large elongated coarse columnar $\alpha-\mathrm{Al}$ matrix together with unmodified eutectic silicon particles. Hence, it is necessary to convert the coarse columnar $\alpha$-Al dendrites to fine equiaxed $\alpha-\mathrm{Al}$ dendrites by using any one of the grain refiners in the form of Ti containing (Al-5Ti), B containing (Al-3B), Ti rich containing (Al-5Ti-1B) and $\mathrm{B}$ rich (Al-1Ti-3B) containing master alloys [3,13-16]. The fine equiaxed grain structure in Al-Si alloy leads to high toughness, high yield strength, improved machinability and uniform distribution of the second phase throughout the material $[6,10]$. The use of grain refiners in castings also helps to improve the die filling and mass feeding to counteract the solidification shrinkage. This results in improved distribution of porosity and better mechanical properties alongwith improved consistency and reliability of castings [17-19].

A single master alloy (grain refiner cum modifier) that serves the purpose of both grain refinement and modification simultaneously is a better option in converting the microstructure of elongated $\alpha$-Al dendrites into fine equiaxed dendrites and needle-like eutectic Si particles (Al-7Si alloy) and primary + eutectic Si particles (Al-11Si alloy) into fine particles [20]. Suárez-Peña and Asensio-Lozano [11] demonstrated improvement in the mechanical properties of Al-12Si alloys by combining chips of two different master alloys, i.e., $0.05 \%$ of Ti and $0.05 \%$ of $\mathrm{Sr}$, to the melt. The advantage of using a single master alloy is that it serves both purposes of grain refinement and modification, thus directly reducing the manufacturing cost and simplifying the foundry operations.

In this study, we developed four different master alloys, namely, binary Al-5Ti, Al-3B, ternary Al-5Ti-1B, and Al1Ti-3B for the grain refinement of Al-7Si alloy. We used the $\mathrm{Al}-3 \mathrm{~B}$ and Al-1Ti-3B master alloys for the grain refinement of the Al-11Si alloy. The modification effect using the Al$10 \mathrm{Sr}$ master alloy was also studied. We also sought to develop a new alloy that could act both as a grain refiner and a modifier, for which the grain refiner and modifier are com- bined. This was resposnbile for a simultaneous grain refinement and modification effcet on $\mathrm{Al}-7 \mathrm{Si}$ and $\mathrm{Al}-11 \mathrm{Si}$ alloys.

\section{EXPERIMENTAL PROCEDURES}

A number of master alloys, Al-5Ti, Al-3B, Al-5Ti-1B, and Al-1Ti-3B, were prepared by the reaction of molten $\mathrm{Al}$ with the halide salts $\mathrm{K}_{2} \mathrm{TiF}_{6}$ and $\mathrm{KBF}_{4}$ at a reaction temperature of $800{ }^{\circ} \mathrm{C}$ and a reaction time of $60 \mathrm{~min}$ in an induction furnace. The processing conditions of these master alloys have been optimized and discussed in detail elsewhere [2]. These indigenously developed master alloys were used for the grain refinement studies in $\mathrm{Al}-7 \mathrm{Si}$ and $\mathrm{Al}-11 \mathrm{Si}$ alloys. Commercial pure aluminum (CPAl) and $\mathrm{Al}-20 \% \mathrm{Si}$ master alloys in required quantities were melted in an electrical resistance furnace under a cover flux $(45 \% \mathrm{NaCl}+45 \% \mathrm{KCl}+10 \%$ $\mathrm{NaF}$ ) and the melt was held at $720{ }^{\circ} \mathrm{C}$ to yield $\mathrm{Al}-7 \mathrm{Si}$ and Al-11Si alloys. After degassing with solid hexachloroethane $\left(\mathrm{C}_{2} \mathrm{Cl}_{6}\right)$, master alloy chips were added to the melt for grain refinement. The melt was stirred for $30 \mathrm{sec}$ with a zirconcoated iron rod after the grain refiner was added, without any further stirring. Parts of the melts were poured at regular intervals of 0,2,5,30,60 and 120 min into a preheated cylindrical graphite mould ( $25 \mathrm{~mm}$ diameter and $100 \mathrm{~mm}$ height) surrounded by fireclay brick with its top open for pouring. More details of the experiments were reported elsewhere $[6,19]$. Table 1 shows the $\%$ of additional levels in different mater alloys to $\mathrm{Al}-7 \mathrm{Si}$ and $\mathrm{Al}-11 \mathrm{Si}$ alloys.

Table 2 shows the \% addition level of the Al-10Sr master alloy to $\mathrm{Al}-7 \mathrm{Si}$ and $\mathrm{Al}-11 \mathrm{Si}$ alloys. For combined grain refinement and modification studies, the indigenously prepared binary Al-Ti, Al-B and ternary Al-Ti-B master alloys were melted individually with the Al-10Sr master alloy in a resistance furnace to form a new combination of ternary AlTi-Sr, Al-B-Sr and quaternary Al-Ti-B-Sr master alloys. Table 3 shows the nomeclature for various master alloys that were used in this investigation. We used these master alloys for simultaneous grain refinement and modification of Al$7 \mathrm{Si}$ and Al-11Si alloys to study the influence of newly developed master alloys. The composition of the master alloys for the preparation was so chosen that the total weight percentage of the newly developed master alloy was equal to the weight percentage of the grain refiner. However, it also con-

Table 1. Optimum addition levels of various master alloys to Al-7Si and Al-11Si alloys

\begin{tabular}{ccccc}
\hline Alloy & Master alloy/Alloy code & $\begin{array}{c}\text { Optimum addition level of } \\
\text { master alloy (wt\%) }\end{array}$ & Ti (\%) & B (\%) \\
\hline Al-7Si & Al-5Ti/M01 & 0.40 & 0.0200 & - \\
Al-7Si & Al-3B/M02 & 0.60 & - & 0.0160 \\
Al-7Si & Al-5Ti-1B/M03 & 0.48 & 0.0240 & 0.0048 \\
Al-7Si & Al-1Ti-3B/M04 & 0.55 & 0.0055 & 0.0120 \\
Al-11Si & Al-3B/M02 & 0.70 & - & 0.0180 \\
Al-11Si & Al-1Ti-3B/M04 & 0.65 & 0.0065 & 0.0140 \\
\hline
\end{tabular}


sised of a percentage of the elements that were present in both the grain refiner and the modifier. In other words, the addition levels of $\mathrm{Ti}, \mathrm{B}$ and $\mathrm{Sr}$ were optimized for the combined grain refinement and modification of the Al-7Si alloy by combining Al-1Ti-3B with Al-10Sr master alloys to form

Table 2. Optimum addition levels of Al-10Sr master alloy to Al7Si and Al-11Si alloy

\begin{tabular}{cccc}
\hline Alloy & $\begin{array}{c}\text { Master alloy/ } \\
\text { Alloy code }\end{array}$ & $\begin{array}{c}\text { Optimum addition level } \\
\text { of master alloy (wt } \%)\end{array}$ & $\operatorname{Sr}(\%)$ \\
\hline Al-7Si & Al-10Sr/M05 & 0.2 & 0.02 \\
Al-11Si & Al-10Sr/M05 & 0.3 & 0.03 \\
\hline
\end{tabular}

Table 3. Newly developed master alloys for Al-7Si and Al-11Si alloys

\begin{tabular}{cccc}
\hline Grain refiner & Modifier & $\begin{array}{c}\text { New master alloy } \\
\text { (combination of grain } \\
\text { refiner cum modifier)/ } \\
\text { Alloy Code }\end{array}$ & Alloy \\
\hline M01 & M05 & Al-5Ti-5Sr/M06 & Al-7Si \\
M02 & M05 & Al-3B-3.3Sr/M07 & Al-7Si \\
M03 & M05 & Al-5Ti-1B-4.2Sr/M08 & Al-7Si \\
M04 & M05 & Al-1Ti-3B-3.6Sr/M09 & Al-7Si \\
M02 & M05 & Al-3B-4.3Sr/M10 & Al-11Si \\
M04 & M05 & Al-1Ti-3B-4.6Sr/M11 & Al-11Si \\
\hline
\end{tabular}

Table 4. Various master alloys with optimum addition levels to Al7Si and Al-11Si alloys

\begin{tabular}{|c|c|c|c|c|}
\hline Alloy & $\begin{array}{l}\text { Optimum addition } \\
\text { level of master alloy } \\
\text { (grain refiner and } \\
\text { modifier) wt \% }\end{array}$ & $\operatorname{Ti}(\%)$ & B (\%) & $\mathrm{Sr}(\%)$ \\
\hline$\overline{\mathrm{A} 1-7 \mathrm{Si}+\mathrm{M} 06}$ & 0.40 & 0.0200 & - & 0.02 \\
\hline $\mathrm{Al}-7 \mathrm{Si}+\mathrm{M} 07$ & 0.60 & - & 0.0160 & 0.02 \\
\hline $\mathrm{Al}-7 \mathrm{Si}+\mathrm{M} 08$ & 0.48 & 0.0240 & 0.0048 & 0.02 \\
\hline $\mathrm{Al}-7 \mathrm{Si}+\mathrm{M} 09$ & 0.55 & 0.0055 & 0.0120 & 0.02 \\
\hline $\mathrm{Al}-11 \mathrm{Si}+\mathrm{M} 10$ & 0.70 & - & 0.0180 & 0.03 \\
\hline $\mathrm{Al}-11 \mathrm{Si}+\mathrm{M} 11$ & 0.65 & 0.0065 & 0.0140 & 0.03 \\
\hline
\end{tabular}

the Al-1Ti-3B-3.6Sr master alloy (i.e., a $0.55 \mathrm{wt} \%$ addition level of Al-1Ti-3B is equal to $0.0055 \% \mathrm{Ti}, 0.012 \% \mathrm{~B}$ and $0.20 \mathrm{wt} \%$ of $\mathrm{Al}-10 \mathrm{Sr}$ is equal to $0.02 \% \mathrm{Sr}$ ). Table 4 shows the details of the combined grain refinement and modification studies on the Al-7Si alloy using M06, M07, M08, and M09 master alloys and the Al-11Si alloy using M10 and M11 master alloys. Table 5 shows the chemical composition of the various master alloys and as cast alloys, which were assessed using an atomic absorption spectrometer, model AA-670, Varian, Netherlands.

The structures of all the experimental materials were characterized by macroscopic studies using Poulton's reagent $\left(60 \% \mathrm{HNO}_{3}+20 \% \mathrm{HCl}+15 \% \mathrm{H}_{2} \mathrm{O}+5 \% \mathrm{HF}\right.$ by volume $)$ and microscopy studies using Keller's reagent $\left(2.5 \% \mathrm{HNO}_{3}\right.$ $+1.5 \% \mathrm{HCl}+1 \% \mathrm{HF}+95 \% \mathrm{H}_{2} \mathrm{O}$ by volume). Microstructural and EDX examinations were carried out using SEM/ EDX (Cam Scan). Dendrite Arm Spacing (DAS) measurements and particle size measurements were carried out using an image analyzer.

\section{RESULTS AND DISCUSSION}

The statistical data obtained from particle size analysis is shown in Table 6 . The sizes of the $\mathrm{Al}_{3}$ Ti particles present in the M01 master alloy were larger than the $\mathrm{AlB}_{2}$ particles that have been observed in various M02 master alloys. The particles in M03 were titanium aluminides while those in M04 were aluminum borides suggesting that the growth rate of

Table 6. Particle size analysis of M01, M02, M03 and M04 master alloys

\begin{tabular}{cccc}
\hline \multirow{2}{*}{ Alloy } & \multicolumn{2}{c}{ Range in $\mu \mathrm{m}$} & \multirow{2}{*}{ Mean $(\mu \mathrm{m})$} \\
\cline { 2 - 3 } & $\min$ & Max. & \\
\hline M01 & 3.8 & 21.6 & 15.6 \\
M02 & 2.1 & 10.1 & 6.9 \\
M03 & 5.4 & 46.7 & 18.3 \\
M04 & 2.2 & 15.1 & 7.6 \\
\hline
\end{tabular}

Table 5. Chemical compositions of various master alloys and base alloys

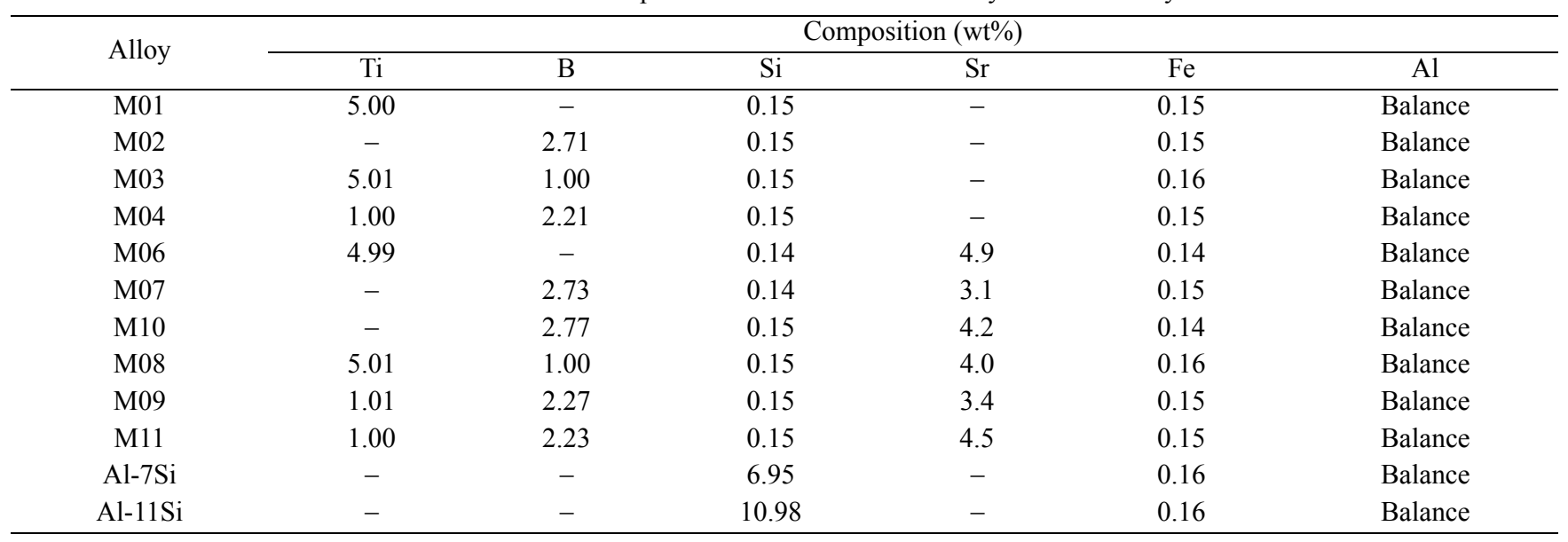




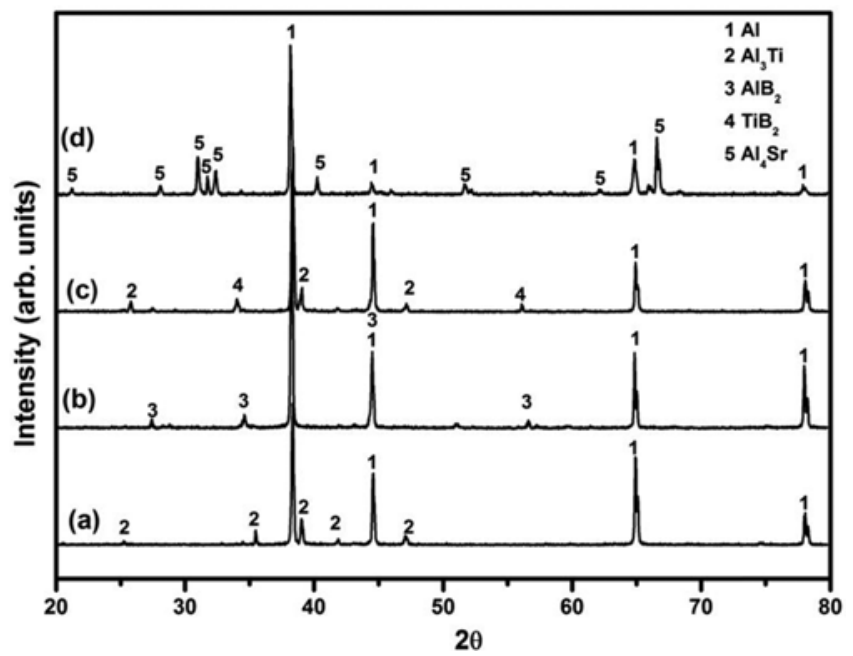

Fig. 1. XRD patterns of (a) M01, (b) M02, (c) M03, and (d) M05 master alloys.

boride particles is much slower than aluminides. Our results were in agreement with earlier studies [3,6,19].

XRD results on the M01 master alloy prepared at $800{ }^{\circ} \mathrm{C}$ 60 min clearly suggest the presence of $\alpha-\mathrm{Al}$ and $\mathrm{Al}_{3} \mathrm{Ti}$ phases (Fig. 1(a)). Our results further suggest that the reaction of $\mathrm{K}_{2} \mathrm{TiF}_{6}$ with molten $\mathrm{Al}$ releases titanium into aluminum, which while crossing the solubility limit, as decided by the Al-Ti phase diagram at the reaction temperature, and forms $\mathrm{TiAl}_{3}$ precipitates. The reaction between $\mathrm{Al}$ and $\mathrm{K}_{2} \mathrm{TiF}_{6}$ is expected to release $\mathrm{Ti}$ in the solid and form $\mathrm{Al}_{3} \mathrm{Ti}$ [21].

Figure 1(b) shows the presence of $\alpha-\mathrm{Al}$ and $\mathrm{AlB}_{2}$ phases in the M02 master alloy. Figure 1(c) shows the presence of $\mathrm{TiAl}_{3}$ and $\mathrm{TiB}_{2}$ compounds in addition to the $\alpha-\mathrm{Al}$ in $\mathrm{M} 03$ master alloy. The alumino-thermic reactions leading to the formation of $\mathrm{TiAl}_{3}, \mathrm{AlB}_{2}$ and $\mathrm{TiB}_{2}$ compounds during the production of Al-Ti-B master alloys are well documented elsewhere [22]. The presence of $\alpha-\mathrm{Al}$ and $\mathrm{Al}_{4} \mathrm{Sr}$ phases can be seen from the XRD results of the M05 alloy (Fig. 1(d)).

Figure 2 shows the XRD peaks of the new combination of ternary and quaternary master alloys, namely, M06, M07, M08 and M09. Figure 2(a) shows the XRD results indicating the presence of the M06 master alloy in which $\alpha-\mathrm{Al}, \mathrm{Al}_{3} \mathrm{Ti}$, $\mathrm{AlSr}$ and $\mathrm{Al}_{4} \mathrm{Sr}$ phases are present. Similarly, $\alpha-\mathrm{Al}, \mathrm{AlSr}$, $\mathrm{Al}_{4} \mathrm{Sr}, \mathrm{AlB}_{2}$ and $\mathrm{SrB}_{6}$ phases are present in the M07 master alloy (Fig. 2(b)). In addition, $\alpha-\mathrm{Al}_{2} \mathrm{Al}_{3} \mathrm{Ti}, \mathrm{Al}_{4} \mathrm{Sr}, \mathrm{SrB}_{6}$ and $\mathrm{TiB}_{2}$ phases are observed in the M08 master alloy (Fig. 2(c)). The presence of $\alpha-\mathrm{Al}, \mathrm{AlB}_{2}$ and $\mathrm{SrB}_{6}$ phases is confirmed in the M09 master alloy (Fig. 2(d)). In view of the overlapping of the $\mathrm{TiB}_{2}$ with $\mathrm{AlB}_{2}$ peaks, $\mathrm{TiB}_{2}$ was not clearly identified. Some researchers [23] believe that $\mathrm{AlB}_{2}$ and $\mathrm{TiB}_{2}$ form a continuous series of solid solutions while others [24-26] believe that the solubility of these two phases is limited and they remain as separate phases.

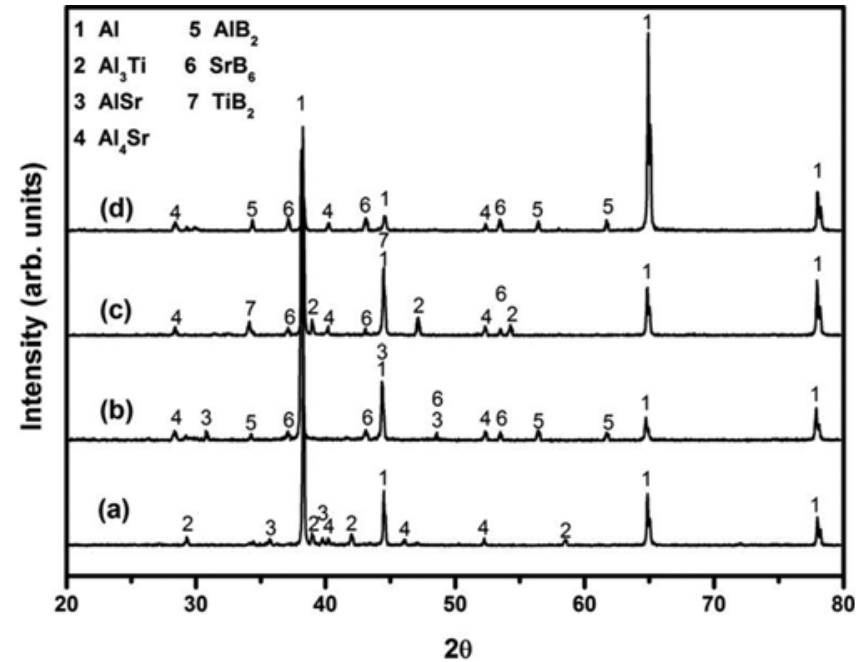

Fig. 2. XRD patterns of master alloys (a) M06, (b) M07, (c) M08, and (d) M09.

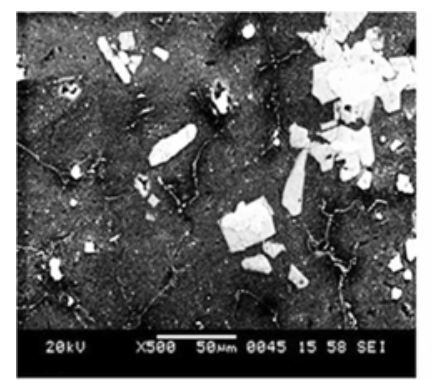

(a)

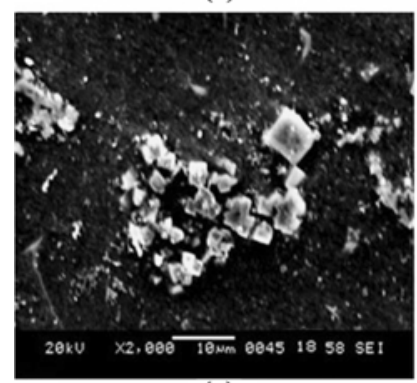

(c)

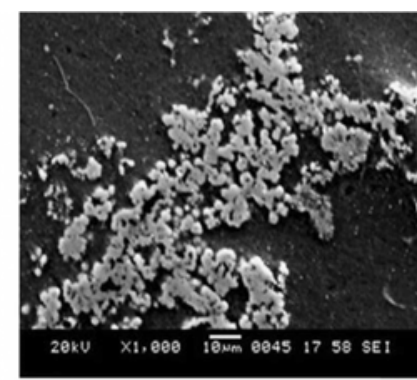

(b)

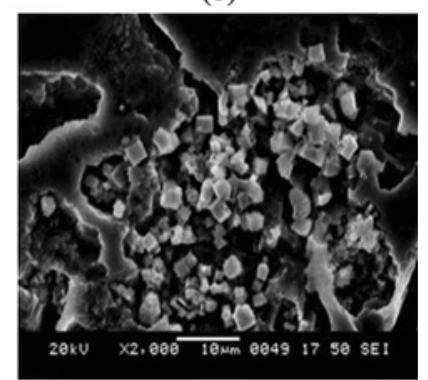

(d)
Fig. 3. SEM images of master alloys (a) M06, (b) M07, (c) M08, and (d) M09.

Figure 3(a) shows the SEM microphotograph of the M06 master alloy and reveals a blocky morphology of $\mathrm{Al}_{3} \mathrm{Ti}$ particles in an $\alpha$-Al matrix along with $\mathrm{Al}_{4} \mathrm{Sr}$ particles. Figure 3(b) shows the SEM images of the M07 master alloy that contains hexagonal shaped aluminum boride intermetallic particles in an $\alpha$-Al matrix. In addition, the strontium reacts with boron particles produces strontium boride particles. The presence of $\mathrm{AlB}_{2}$ and $\mathrm{SrB}_{6}$ phases were confirmed from XRD studies and are shown in Fig. 2(b). Figure 3(c) shows the SEM microphotograph of the M08 master alloy in which $\mathrm{Al}_{3} \mathrm{Ti}, \mathrm{Al}_{4} \mathrm{Sr}$ and $\mathrm{SrB}_{6}$ particles in an $\alpha-\mathrm{Al}$ matrix can be clearly seen. Figure 3(d) shows the SEM microphotograph 


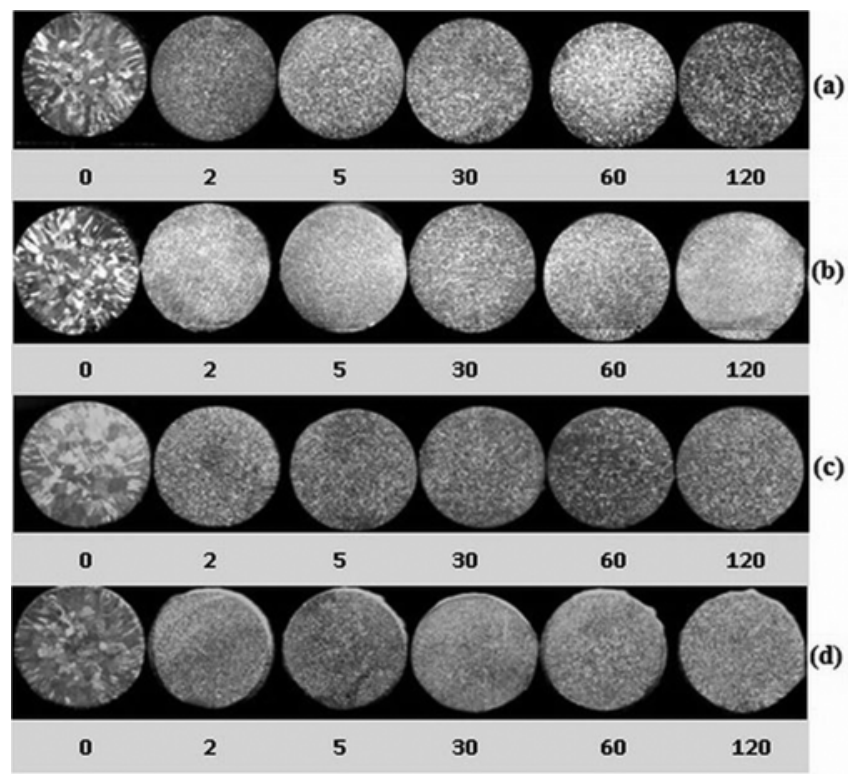

Fig. 4. Macrophotographs of Al-7Si alloy without addition of grain refiner (0 min, samples) and with optimum addition level of (a) 0.40 wt $\%$ of M01, (b) $0.60 \mathrm{wt} \%$ of M02, (c) $0.48 \mathrm{wt} \%$ of M03, and (d) 0.55 $\mathrm{wt} \%$ and $\mathrm{M} 04$.

of the M09 master alloy. The high B-containing M04 master alloy consists of mixed boride particles, $\mathrm{AlB}_{2}$ and $\mathrm{TiB}_{2}$ in an $\alpha$-Al matrix, but both have similar crystal structures and identical lattice parameters. Both differ in their lattice parameters only by about $0.6 \%$ and $1.0 \%$ respectively [17]. These mixed borides have lower solubility in $\mathrm{Al}$ than $\mathrm{AlB}_{2}$, but still may be close enough in structure to $\mathrm{AlB}_{2}$ [17]. This result suggests that there is overlapping of the $\mathrm{TiB}_{2}$ phase over the $\mathrm{AlB}_{2}$ phase. This supports the view in $[3,23]$ that $\mathrm{AlB}_{2}$ and $\mathrm{TiB}_{2}$ coexist.

Figure 4 shows the macro photographs of the Al-7Si alloy with and without a grain refiner. In all the macrographs, 0 min refers to no grain refiner additions. From Fig. 4(a), it is clear that the Al-7Si alloy has a coarse columnar dendritic structure $(0 \mathrm{~min})$ when no grain refiner was added to the melt. However, with the addition of $0.02 \%$ Ti using the M01 master alloy (Fig. 4(b)), the Al-7Si alloy exhibited a response towards grain refinement with a structural transition from a coarse columnar structure to an equiaxed structure after a holding time of 2 min Such structural changes could be due to the presence of $\mathrm{Al}_{3} \mathrm{Ti}$ particles in the M01 master alloy, which provides heterogeneous nucleating sites during solidification. However, on holding the melt beyond $5 \mathrm{~min}$, an equiaxed structure in the Al-7Si alloy was observed at all holding times (5-120 min). The M01 master alloy with finer blocky $\mathrm{Al}_{3} \mathrm{Ti}$ crystals shows that the grain refinement effect did not fade away even at longer holding periods [27]. Arnberg et al. [28] suggested that blocky aluminides are probably more efficient nucleating sites than flaky and petal like crystals with their (011) surfaces providing suitable sub-

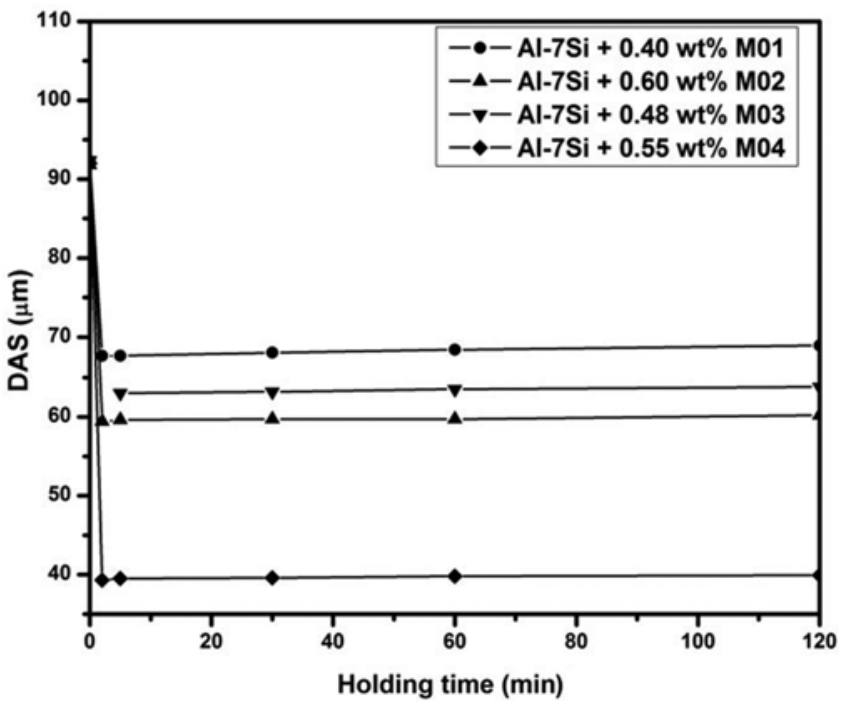

Fig. 5. DAS analysis of Al-7Si alloy with optimum addition levels of various grain refiners.

strates on which the (012) planes of aluminum can nucleate. The size of the intermetallic particles will impact on the settling rate and Stoke's law predicts that larger particles settle more quickly than smaller particles [29]. Therefore, the macroscopic results clearly suggest that the size, morphology and size distribution of $\mathrm{Al}_{3}$ Ti particles have a great influence on the grain refining efficiency of the M01 master alloy.

Figure 4(b) shows the photo macrographs of the Al-7Si alloy with $0.60 \mathrm{wt} \%$ of the M02 master alloy addition. As expected, it exhibited a columnar structure in the absence of grain refining ( 0 min sample), and the 2 min sample showed grain refinement, which could be due to the presence of uniformly distributed fine hexagonal $\mathrm{AlB}_{2}$ particles present in the M02 master alloy. Figure 4(c) shows the influence of addition of $0.48 \mathrm{wt} \%$ of the ternary M03 master alloy on the macrostructures of the Al-7Si alloy at different holding times. Better grain refining performance at all holding times (2-120 $\mathrm{min}$ ) was observed. Figure 4(d) represents the macro photographs of the Al-7Si alloy grain refined with the addition of $0.55 \mathrm{wt} \%$ of the M04 master alloy.

Figure 5 shows the results of DAS analysis of the Al-7Si alloy grain refined with optimum addition levels of various master alloys $(0.40 \mathrm{wt} \%$ of M01, $0.60 \mathrm{wt} \%$ of M02, 0.48 wt $\%$ of M03 and 0.55 wt $\%$ of M04). From Fig. 5, it is clear that in the absence of a grain refiner, the Al-7Si alloy has a DAS value of $92 \mu \mathrm{m}$. However, with the optimum addition of $0.40 \mathrm{wt} \%$ of M01, a DAS value of $67.6 \mu \mathrm{m}$ was observed at a shorter holding period of $2 \mathrm{~min}$, while on prolonged holding periods (from 2 to $120 \mathrm{~min}$ ), the change in DAS values was found to be insignificant $(67.6 \mu \mathrm{m}, 68.0 \mu \mathrm{m}, 68.4$ $\mu \mathrm{m}$ and $68.9 \mu \mathrm{m})$. Such a decrease in DAS values as observed on longer holding periods could be due to the presence of large fractions and more fine blocky $\mathrm{Al}_{3}$ Ti particles 
of the M01 master alloy, which act as nucleating sites for solidification of $\alpha$-Al.

The optimum addition level of $0.60 \mathrm{wt} \%$ of the M02 master alloy to the Al-7Si alloy resulted in a DAS value of 59.4 $\mu \mathrm{m}$ at a holding period of $2 \mathrm{~min}$, and it remained almost constant even at longer holding times from 2 to $120 \mathrm{~min}$ as shown in Fig. 5. This could be attributed to the fact that the M02 master alloy contained larger volume fractions of homogeneously distributed fine hexagonal $\mathrm{AlB}_{2}$ particles that act as nucleating sites during solidification and result in refinement of the structure.

Addition of $0.48 \mathrm{wt} \%$ of the M03 master alloy to $\mathrm{Al}-7 \mathrm{Si}$ results in a DAS value of $62.9 \mu \mathrm{m}$ in both shorter $(2 \mathrm{~min})$ and longer (120 min) holding times. The decrease in DAS values obtained after the addition of a grain refiner is due to the presence of $\mathrm{Al}_{3} \mathrm{Ti}$ and $\mathrm{TiB}_{2}$ intermetallic particles, in the M03 maser alloy, which act as nucleating sites during solidification thereby decreasing the dendritic arm spacing. A decrease in DAS value from $92 \mu \mathrm{m}$ (Al-7Si alloy) to 39.3 $\mu \mathrm{m}$ was observed at a $2 \mathrm{~min}$ holding period with the addition of $0.55 \mathrm{wt} \% \mathrm{M} 04$ master alloy to the Al-7Si alloy and this value of $39.3 \mu \mathrm{m}$ remained constant up to a $120 \mathrm{~min}$ holding time. The M04 master alloy contained $\mathrm{AlB}_{2}$ particles and a Ti bearing phase, so probably (Al, Ti) $\mathrm{B}_{2}$ was present at the edge of such particles. The possibility of $\mathrm{AlB}_{2}$ reacting with the Ti bearing phase, $(\mathrm{Al}, \mathrm{Ti}) \mathrm{B}_{2}$ or $\mathrm{Al}_{3} \mathrm{Ti}$, resulting in the formation of $\mathrm{TiB}_{2}$ cannot be ruled out. Such $\mathrm{TiB}_{2}$ particles are also expected to take part in the nucleation events. This explains the better performance of the M04 master alloy over other master alloys in the grain refinement of the Al-7Si alloy. A decrease in the DAS value from $92 \mu \mathrm{m}$ to $39.3 \mu \mathrm{m}$ clearly coincides with macrostructural details of Fig. 4(d) indicating conversion of a columnar structure to an equiaxed structure.

Figure 6(a) shows SEM microphotographs of the Al-7Si alloy in the absence of a grain refiner $(0 \mathrm{~min})$. It is clear from the figure that the alloy solidifieed with a columnar dendritic structure, in the absence of a grain refiner, with large eutectic $\mathrm{Si}$ needles/flakes at the grain boundaries of the columnar $\alpha$ $\mathrm{Al}$ dendrites. Good grain refinement of the $\alpha$-Al dendrites was observed, as in Fig. 6(b), when a $0.40 \mathrm{wt} \%(0.0200 \%$ Ti) M01 master alloy was added to the Al-7Si alloy. The addition of $0.40 \%$ of the M01 master alloy significantly refined the $\alpha-\mathrm{Al}$ dendrites and converted them from columnar to fine equiaxed dendrites. However, the eutectic $\mathrm{Si}$ remained in the unmodified eutectic needle form. In other words, addition of a grain refiner does not affect eutectic Si.

Good grain refinement of $\alpha$-Al dendrites was observed, as in Fig. 6(c), with the addition of $0.60 \mathrm{wt} \%(0.0160 \%$ B) of the M02 master alloy to the Al-7Si alloy. Figure 6(d) shows the SEM microphotograph of the Al-7Si alloy grain refined with $0.48 \mathrm{wt} \%(0.0240 \% \mathrm{Ti})$ addition level of the M03 master alloy. Figure 6(e) shows the SEM microphotograph of the

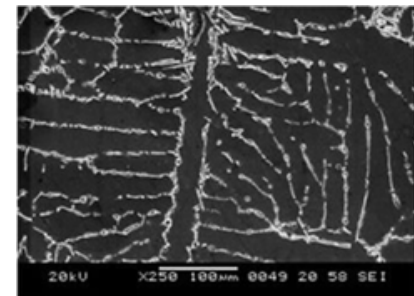

(a)

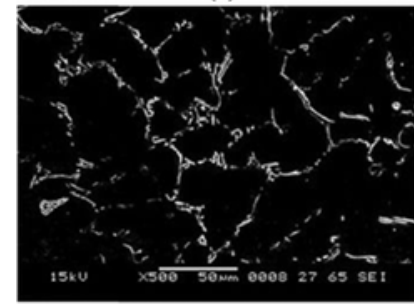

(c)

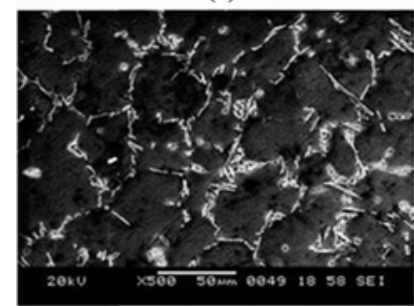

(e)

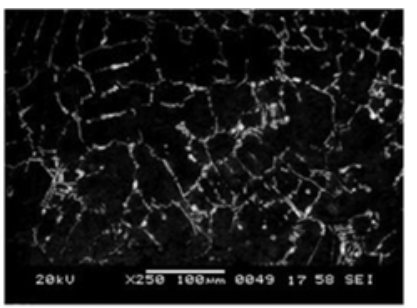

(b)

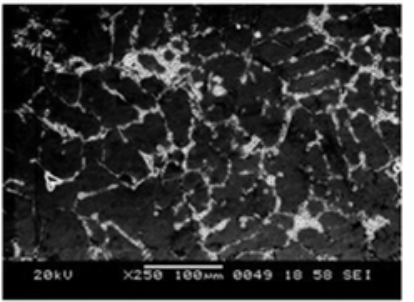

(d)

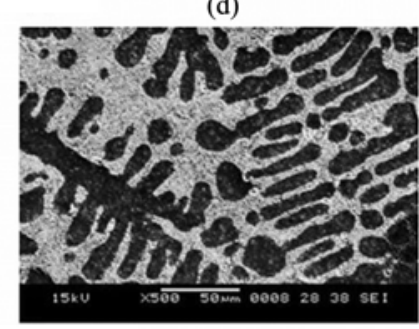

(f)
Fig. 6. SEM images of Al-7Si alloy (a) without addition of grain refiner and with (b) $0.40 \mathrm{wt} \%$ of M01, (c) $0.60 \mathrm{wt} \%$ of M02, (d) 0.48 $\mathrm{wt} \%$ of M03, (e) $0.55 \mathrm{wt} \%$ of M04 and (f) with $0.20 \mathrm{wt} \%$ of M05.

Al-7Si alloy with a $0.55 \mathrm{wt} \%$ addition level of the M04 master alloy. The figure clearly reveals that the Al-7Si alloy responded to grain refinement by forming fine equiaxed $\alpha$ $\mathrm{Al}$ dendrites with eutectic $\mathrm{Si}$ at the grain boundaries in the unmodified condition. This is due to the presence of mixed boride (Al,Ti) $\mathrm{B}_{2}$ particles present in the M04 master alloy. These particles in the master alloy are responsible to act as nucleating sites during solidification. Figure 6(f) shows the SEM microphotograph of the Al-7Si alloy with a $0.20 \mathrm{wt} \%$ addition level of the M05 master alloy. It is clear that in the absence of a modifier (Fig. 6(a)), the structure of the Al-7Si alloy consists of unmodified eutectic silicon in the form of needles together with elongated columnar $\alpha$-Al dendrites. However, individual additions of $0.20 \mathrm{wt} \%$ of the M05 master alloy to the Al-7Si alloy converted the flake particles of silicon into fine particles of silicon, which is confirmed in Fig. 6(f).

It is clear that optimum addition level of $0.40 \mathrm{wt} \%$ of the M06 master alloy to the Al-7Si alloy leads to the formation of a uniform equiaxed $\alpha$-Al structure for holding times between 2 to $60 \mathrm{~min}$ (Fig. 7(a)). However, on holding the melt beyond $60 \mathrm{~min}$, a partial coarsening of the structure was observed, suggesting fading/poisoning due to the settling/ dissolution of the $\mathrm{Al}_{3}$ Ti nucleating particles present in the M06 master alloy, which is clear from Fig. 7(a) (120 min). 


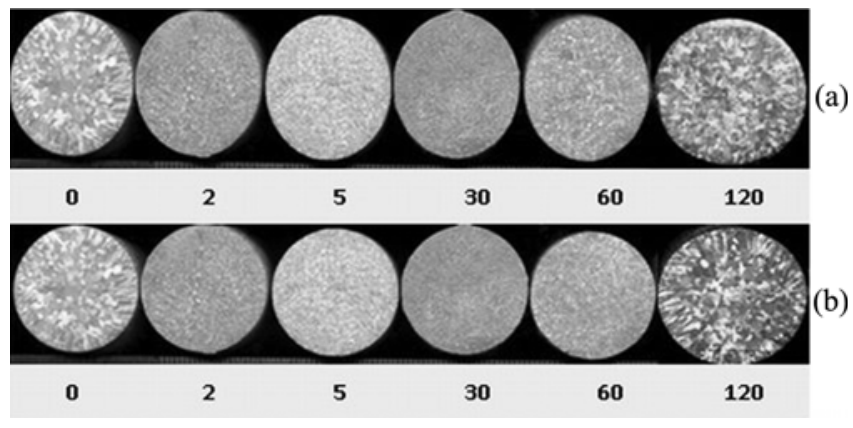

Fig. 7. Macrophotographs of Al-7Si alloy without addition of grain refiner ( 0 min samples) and with optimum addition levels of (a) 0.40 wt $\%$ of M06 and (b) $0.55 \mathrm{wt} \%$ of M09.

During the process of grain refinement of the $\mathrm{Al}-7 \mathrm{Si}$ alloy with the optimum addition level of the M01 master alloy, $\mathrm{Al}_{3}$ Ti particles did not settle at the bottom because of its density $\left(3.4 \mathrm{~g} / \mathrm{cm}^{3}\right)$ [30]. Macrophotographs of the grain refined and modifed Al-7Si alloy with $0.55 \mathrm{wt} \%$ of the M09 master alloy clearly indicates that holding periods up to $60 \mathrm{~min}$ produced good grain refinement and modification results. However, a coarsening effect on $\mathrm{Al}$ is evident after $60 \mathrm{~min}$ of holding time (Fig. 7(b)). The results are in consistent with an earlier report [2].

DAS analysis of the Al-7Si alloy with optimum addition levels of the new combination of grain refiner cum modifier is shown in Fig. 8. Addition of $0.40 \mathrm{wt} \%$ of the M06 master alloy to the Al-7Si resulted in a DAS value of $68.5 \mu \mathrm{m}$ for 2 min and continued to remain at this value up to $60 \mathrm{~min}$ of holding while prolonged holding from 60-120 min, resulted in an increase of the value to $82.1 \mu \mathrm{m}$. Such an increase in the DAS observed on longer holding periods clearly suggests fading/poisoning due to the settling/dissolution of the

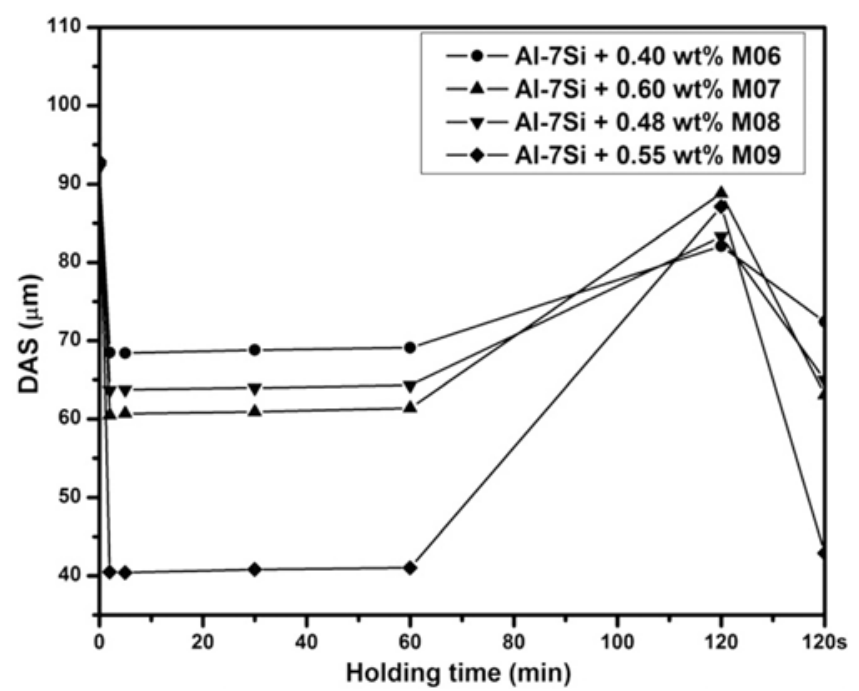

Fig. 8. DAS analysis of Al-7Si alloy with optimum addition levels of $0.40 \mathrm{wt} \%$ of M06, $0.60 \mathrm{wt} \%$ of M07, $0.48 \mathrm{wt} \%$ of M08 and $0.55 \mathrm{wt} \%$ of M09. nucleating particles. In Fig. 8, 120s indicates that the melt was stirred for $10 \mathrm{~s}$ after a holding time of $120 \mathrm{~min}$ and was then poured. DAS analysis on the 120 s min sample of the Al-7Si alloy treated with the M06 alloy revealed a dramatic recovery of the DAS value up to $72.4 \mu \mathrm{m}$. Thus, the settling of the nucleating particles was confirmed with the DAS value obtained from the $120 \mathrm{~min}$ sample. Similarly, addition of $0.60 \mathrm{wt} \%$ of the M07 master alloy to the Al-7Si alloy resulted in an almost constant DAS value of $60.5 \mu \mathrm{m}$ (2-60 min). This could be due to the presence of $\mathrm{AlB}_{2}$ and $\mathrm{Al}_{4} \mathrm{Sr}$ nucleating particles present in the melt. On holding the melt beyond $60 \mathrm{~min}$, an increase in the DAS value of $88.8 \mu \mathrm{m}$ was observed $(120 \mathrm{~min})$. This could be due to the formation of a $\mathrm{SrB}_{6}$ phase that tends to settle down in the melt after 60 min of holding. The recovery of the settled nucleating particles was confirmed with the DAS value of $63.1 \mu \mathrm{m}$ obtained from the $120 \mathrm{~s}$ min sample. Addition of $0.48 \mathrm{wt} \%$ of the M08 master alloy to the Al-7Si alloy resulted in a DAS value of $63.7 \mu \mathrm{m}$, which remained almost constant from 2-60 min of holding, and a DAS value of $83.3 \mu \mathrm{m}$ was obtained for the 120 min sample.

Figure 9(a) shows that addition of $0.40 \mathrm{wt} \%$ of the M06 master alloy to the Al-7Si alloy resulted in grain refinement of $\alpha-\mathrm{Al}$ dendrites from coarse columnar to fine equiaxed. In addition, the alloy also showed good modification of eutectic

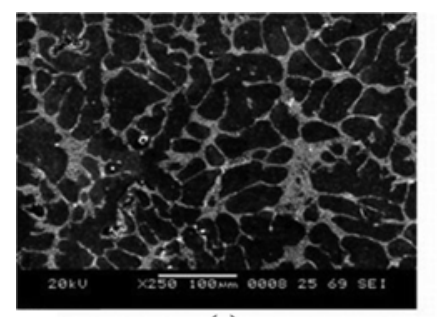

(a)

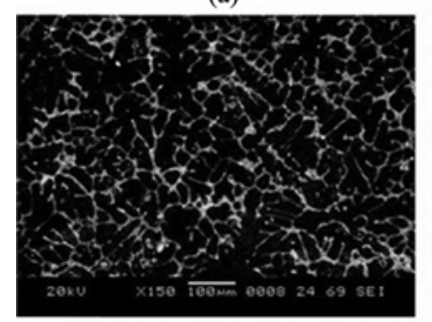

(c)

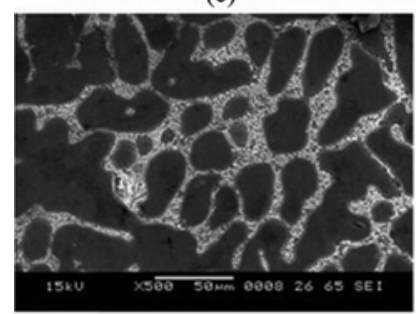

(e)

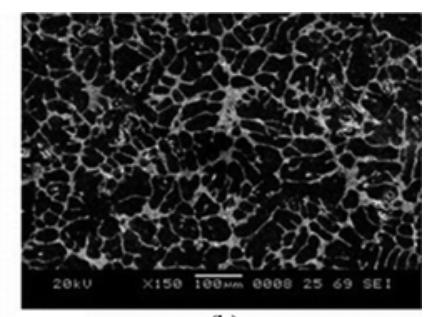

(b)

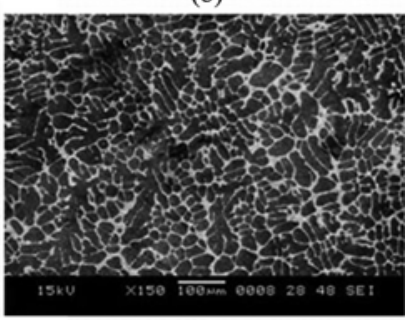

(d)

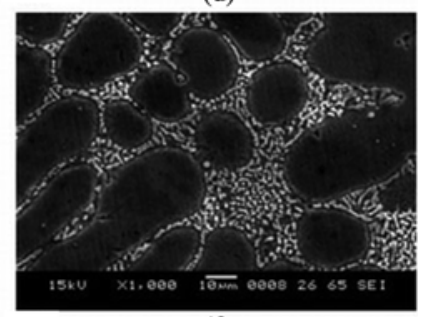

(f)
Fig. 9. SEM microphotographs of Al-7Si alloy with (a) $0.40 \mathrm{wt} \%$ of M06 (b) $0.60 \mathrm{wt} \%$ of M07 (c) $0.48 \mathrm{wt} \%$ of M08 and (d) $0.55 \mathrm{wt} \%$ of M09 at low (e) and high (f) magnifications. 


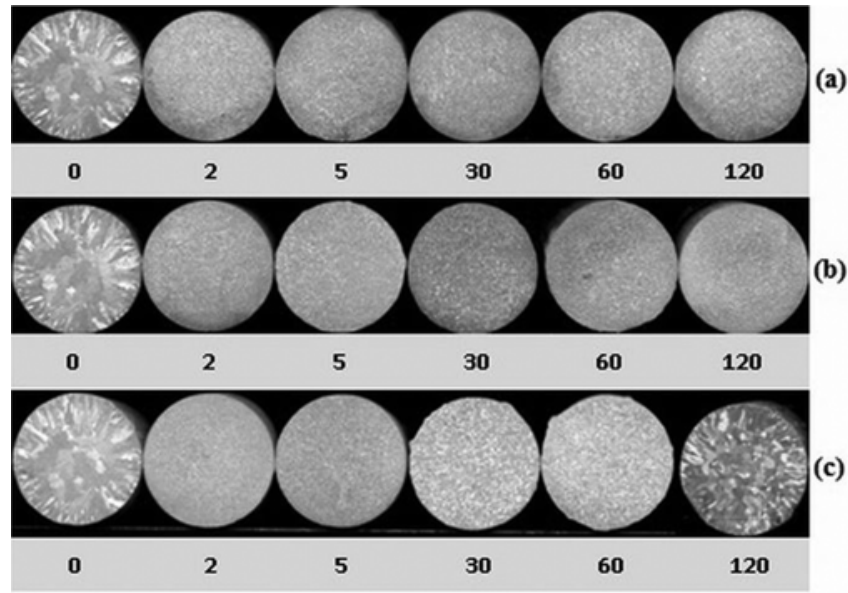

Fig. 10. Macrophotographs of Al-11Si allow without addition of grain refiner (0 min samples) and with optimum addition levels of (a) 0.70 wt $\%$ of M02, (b) $0.65 \mathrm{wt} \%$ of M04 and (c) $0.65 \mathrm{wt} \%$ of M11.

$\mathrm{Si}$. This is due to the presence of $\mathrm{Al}_{3} \mathrm{Ti}$ and $\mathrm{Al}_{4} \mathrm{Sr}$ particles. Addition of $0.60 \mathrm{wt} \%$ of the M07 master alloy to the Al-7Si alloy showed a (Fig. 9(b)) clear structural refinement of $\alpha-\mathrm{Al}$ dendrites as well as modification of eutectic $\mathrm{Si}$, which was similar to that obtained in Fig. 9(a). This could be due to the formation of potential $\mathrm{AlB}_{2}$ and $\mathrm{Al}_{4} \mathrm{Sr}$ nucleating particles. Addition of a Ti-rich and Sr-containing master alloy $(0.48$ $\mathrm{wt} \%$ of M08) to the Al-7Si alloy resulted in a combined good grain refinement and modification effect as shown in Fig. 9(c), which could be due to the presence of $\mathrm{Al}_{3} \mathrm{Ti}_{1}, \mathrm{TiB}_{2}$ and $\mathrm{Al}_{4} \mathrm{Sr}$ particles. Addition of a B-rich and Sr-containing master alloy ( $0.55 \mathrm{wt} \%$ of M09) to the Al-7Si alloy also resulted in a complete structural transition from an $\alpha$-Al dendritic structure into a fine equiaxed $\alpha$-Al dendritic structure as well as conversion of plate-like $\mathrm{Si}$ particles into fine $\mathrm{Si}$ particles, which is evident from Fig. 9(d). The grain refinement cum modification effect of the M09 master alloy on the Al-7Si alloy is shown at higher magnifications in Fig. 9(d,e). In our study, SEM microphotographs of Al-7Si and Al-11Si grain refined and/or modified by various master alloys were taken for a 30 min sample. Thus, the results of SEM (Fig. 9) correlate with the macroscopic observations (Fig. 7) and DAS analysis (Fig. 8).

Figure 10 represents macro photographs of the $\mathrm{Al}-11 \mathrm{Si}$ alloy without addition of a grain refiner ( 0 min samples) along with optimum addition levels of conventional and newly developed master alloys. It is clear from the figure that after the addition of $0.70 \mathrm{wt} \%$ of M02 (Fig. 10(a)) and $0.65 \mathrm{wt} \%$ of M04 (Fig. 10(b)) master alloys to the Al-11Si alloy, an elongated form of $\alpha-\mathrm{Al}$ was converted into fine equiaxed dendrites, which were distributed throughout the melt up to longer time holdings (120 min). Macrophotographs of the Al-11Si alloy treated with $0.65 \mathrm{wt} \%$ of the M11 master alloy (Fig. 10(c)) clearly indicate that good grain

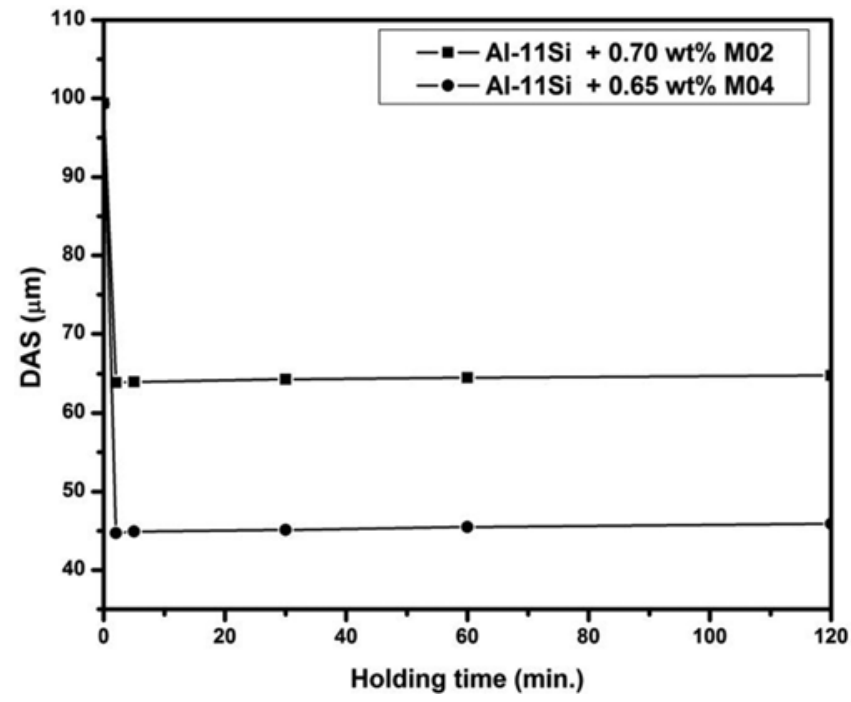

Fig. 11. DAS analysis of Al-11Si alloy with $0.70 \mathrm{wt} \%$ of M02 and $0.65 \mathrm{wt} \% \mathrm{M} 04$.

refinement of $\alpha$-Al was obtained from 2 to 60 min of holding, beyond which the equiaxed structure was transformed back to a columnar structure.

Figure 11 reveals that the Al-11Si alloy in the absence of a grain refiner and/or modifier had a DAS value of $99.4 \mu \mathrm{m}$, because of the columnar distribution of the $\alpha$-Al matrix. With the addition of $0.70 \mathrm{wt} \%$ of the M02 master alloy and $0.65 \mathrm{wt} \%$ of the M04 master alloy, the columnar $\alpha-\mathrm{Al}$ present in the Al-11Si melt was transformed into an equiaxed structure at all holding times from 2 to120 min (Fig. 11(a)). This is attributed to a decrease in the DAS value of the Al-11Si alloy (with addition of $0.70 \mathrm{wt} \%$ of the M02 master alloy) from $99.4 \mu \mathrm{m}$ to $63.9 \mu \mathrm{m}$ at $2 \mathrm{~min}$ of holding time, and this value remained almost constant up to $120 \mathrm{~min}$ of holding. This could be due to the presence of $\mathrm{AlB}_{2}$ particles in the melt. However, a large number eutectic Si particles together with small number of primary Si particles was unaffected and tended to remain in the needle and blocky type. With an addition of $0.65 \mathrm{wt} \%$ of the M04 master alloy to the Al-11Si alloy, a decrease in the DAS value of $44.7 \mu \mathrm{m}$ was obtained, at both shorter and at longer holding periods. The transformation is due to the presence of mixed boride (Al, Ti) $\mathrm{B}_{2}$ particles in the melt, which take part as positive nucleating sites during the solidification of the melt. The eutectic Si remained in the unaltered form of needles and primary Si remained in a star shape. Addition of $0.30 \mathrm{wt} \% \mathrm{M} 05$ master alloy to the Al-11Si alloy resulted in partial refinement of aluminum together with conversion of eutectic $\mathrm{Si}$ and primary Si particles into fine fibrous particles.

Figure 12 shows the results of DAS analysis of the Al$11 \mathrm{Si}$ alloy that was grain refined cum modified with optimum addition levels of $0.70 \mathrm{wt} \% \mathrm{M} 10$ and $0.65 \mathrm{wt} \%$ of M11 master alloys. It clearly shows that in the absence of a grain 


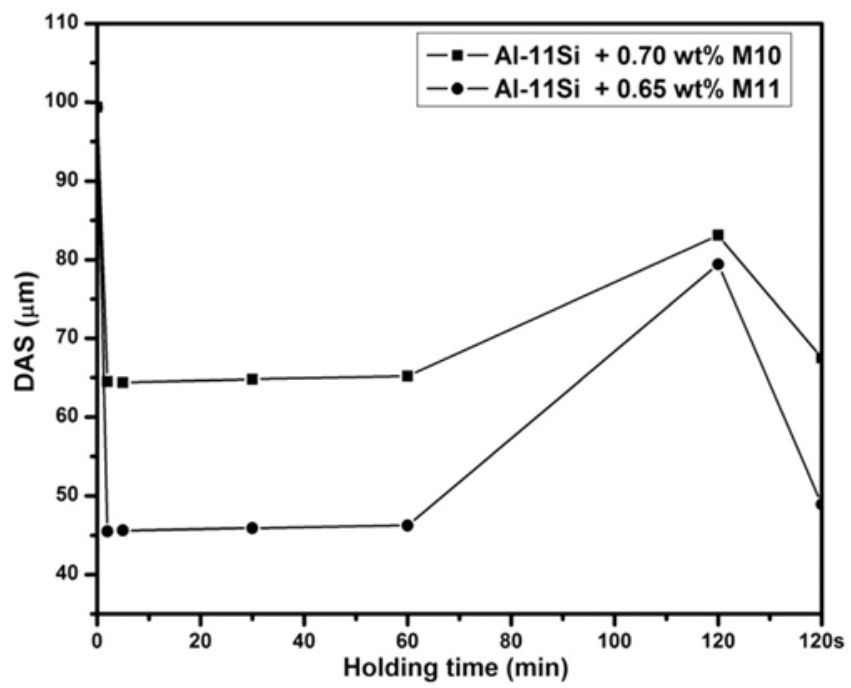

Fig. 12. DAS analysis of Al-11Si alloy with optimum addition levels of $0.70 \mathrm{wt} \%$ of M10 and $0.65 \mathrm{wt} \%$ of M11.

refiner and/or modifier the Al-11Si alloy had a DAS value of $99.4 \mu \mathrm{m}$. However, the addition of $0.70 \mathrm{wt} \%$ of the M10 master alloy and $0.65 \mathrm{wt} \%$ of the M11 master alloy to the Al-11Si alloy resulted in decreased DAS values of 64.5 and $45.5 \mu \mathrm{m}$, which almost remained constant from 2-60 min of holding. However, on prolonged holding up to $120 \mathrm{~min}$, a rapid increase in DAS values were obtained, i.e., from 64.5 $\mu \mathrm{m}$ to $83.1 \mu \mathrm{m}$ for the M10 master alloy and from $45.5 \mu \mathrm{m}$ to $79.4 \mu \mathrm{m}$ for the M11 master alloy. This drastic increase in DAS values could be due to the settling of nucleating $\mathrm{AlB}_{2}$, $\mathrm{Al}_{4} \mathrm{Sr}$ and $\mathrm{SrB}_{6}$ particles (in the M10 master alloy) and (Al,Ti) $\mathrm{B}_{2}$ and $\mathrm{SrB}_{6}$ particles (in the M11 master alloy). Recovery of these particles took place for the 120 s min samples resulting in DAS values decreasing from $83.1 \mu \mathrm{m}$ to $67.5 \mu \mathrm{m}$ (the M09 master alloy) and $79.4 \mu \mathrm{m}$ to $48.9 \mu \mathrm{m}$ (the M10 master alloy). The Al-11Si alloy treated with both master alloys had no effect on eutectic Si or primary Si.

Figure 13 shows the SEM microphotographs of Al-11Si alloy before and after the addition of optimum addition levels of various master alloys. The microstructure of the Al$11 \mathrm{Si}$ alloy consisted primarily of a eutectic mixture $(\alpha-\mathrm{Al}+$ $\mathrm{Si})$ with a considerable number of elongated $\alpha$-Al dendrites and a few primary Si particles. Normally, the Al-11Si alloy should consist of only a eutectic mixture, if it solidifies under equilibrium cooling conditions. The presence of $\alpha-\mathrm{Al}$ as well as primary silicon particles indicates that the cooling was much faster than equilibrium cooling conditions. The presence of $\alpha-\mathrm{Al}$ as well as the primary silicon was due to the concept of skewed coupled zone. Figure 13(a) clearly shows the eutectic mixture is an irregular (divorced eutectic) mixture consisting of large plate/needle-like Si particles grown in a matrix of $\alpha-\mathrm{Al}$. We infered from Figs. 13(b) and (c) that the addition of $0.70 \mathrm{wt} \%$ of the M02 master alloy and

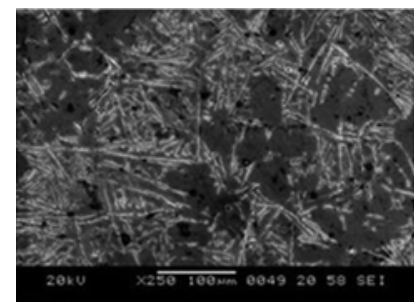

(a)

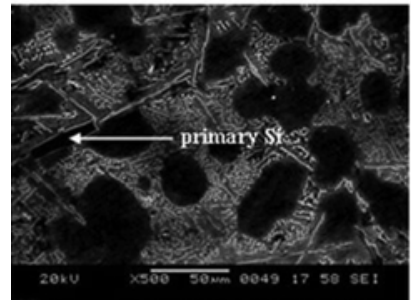

(c)

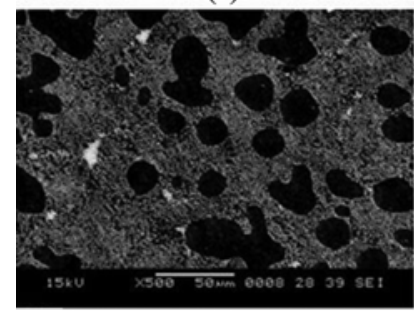

(e)

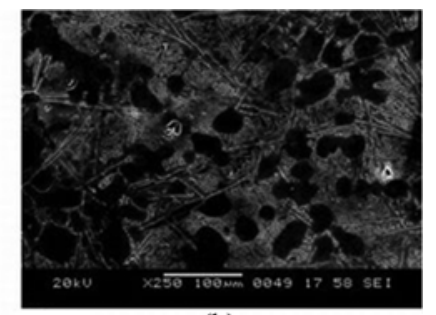

(b)

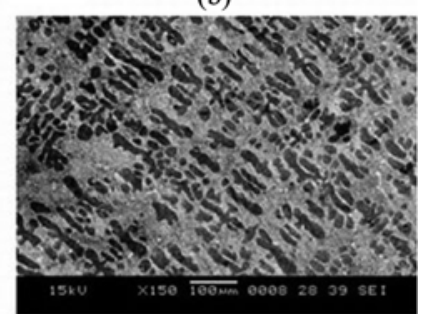

(d)

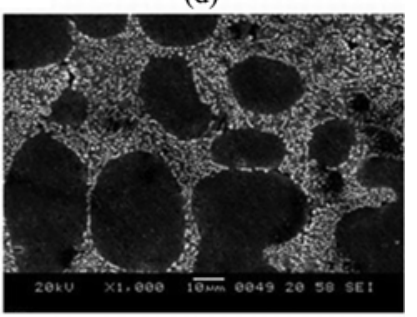

(f)
Fig. 13. SEM images of Al-11Si alloy (a) without addition of grain refiner and modifier, with optimum addition level of (b) $0.70 \mathrm{wt} \%$ of M02 (c) $0.65 \mathrm{wt} \%$ of M04 (d) $0.30 \mathrm{wt} \%$ of M05, (e) $0.70 \mathrm{wt} \%$ of M10 and (f) $0.65 \mathrm{wt} \%$ of M11.

$0.65 \mathrm{wt} \%$ of the M04 master alloy to the Al-11Si alloy resulted in fine equiaxed $\alpha$-Al dendrites, whereas the $\mathrm{Si}$ remained in the unmodified form. Figure 13(d) shows wellmodified structures of more finely dispersed eutectic and primary silicon, but $\alpha-\mathrm{Al}$ remains in the columnar form after addition of $0.30 \mathrm{wt} \%$ of the M05 master alloy. Figure 13(e) and (f) shows that optimum additions of $0.70 \mathrm{wt} \%$ of the M10 master alloy and $0.65 \mathrm{wt} \%$ of the M11 master alloy to the Al-11Si alloy, respectively, were sufficient for complete grain refinement of the $\alpha$-Al dendrites and modification of the eutectic silicon and primary silicon into fine fibrous form.

The tensile properties of the Al-7Si alloy depends on the shape and size of the $\alpha$-Al grains and eutectic silicon, and in the Al-11Si alloy they depend on primary silicon in addition to $\alpha-\mathrm{Al}$ grains and eutectic silicon. The addition of a grain refiner to Al-7Si and Al-11Si alloys predominantly converted the columnar dendritic structure to a fine equiaxed dendritic structure, thereby enhancing the mechanical properties. In order to avoid the fracture of eutectic Si in the Al7Si alloy a modifier was added that converted the eutectic silicon to fine particles (rounded), and in the Al-11Si alloy, it transformed the primary and eutectic silicon to fine particles, thereby increasing the toughness, tensile stress, and ductility. Further improvements in mechanical properties were observed 
Table 7. Mechanical properties of Al-7Si and Al-11Si alloys

\begin{tabular}{|c|c|c|c|c|c|}
\hline Alloy & $\begin{array}{l}\text { Addition Level of } \\
\text { Grain Refiner (\%) }\end{array}$ & $\begin{array}{l}\text { Addition level of } \\
\text { Modifier (\%) }\end{array}$ & $0.2 \%$ Proof Stress & UTS (MPa) & $\% \mathrm{E}$ \\
\hline Al-7Si & - & - & 53.0 & 145.0 & 08.0 \\
\hline $\mathrm{Al}-7 \mathrm{Si}+0.55 \% \mathrm{M} 04$ & 0.55 & - & 57.5 & 155.0 & 10.5 \\
\hline $\mathrm{Al}-7 \mathrm{Si}+0.20 \% \mathrm{M} 05$ & - & 0.02 & 58.3 & 157.3 & 11.0 \\
\hline $\mathrm{Al}-7 \mathrm{Si}+0.55 \% \mathrm{M} 09$ & 0.55 & 0.02 & 62.0 & 160.0 & 13.0 \\
\hline $\mathrm{Al}-11 \mathrm{Si}$ & - & - & 59.4 & 150.9 & 09.5 \\
\hline $\mathrm{Al}-11 \mathrm{Si}+0.65 \% \mathrm{M} 04$ & 0.65 & - & 62.9 & 157.4 & 11.6 \\
\hline $\mathrm{Al}-11 \mathrm{Si}+0.30 \% \mathrm{M} 05$ & - & 0.03 & 67.1 & 178.9 & 12.9 \\
\hline $\mathrm{Al}-11 \mathrm{Si}+0.65 \% \mathrm{M} 11$ & 0.65 & 0.03 & 69.4 & 184.3 & 14.6 \\
\hline
\end{tabular}

with the combined addition of grain refiner and modifier as compared to the individual addition of grain refiner and/or modifier (Table 7). In the absence of a grain refiner the Al$7 \mathrm{Si}$ alloy exhibited $0.2 \%$ proof stress, ultimate tensile strength (UTS) and \% elongations of $53 \mathrm{MPa}, 145 \mathrm{MPa}$ and $8.2 \%$, respectively. However, with the addition of conventional master alloys (M03 and M05), the tensile properties of the Al-7Si alloys were enhanced as is evident from Table 7. The improvement in the $0.2 \%$ proof stress of the Al-7Si alloy obtained with the addition of B-rich M09 and M05 master alloys corresponded to $57.5 \mathrm{MPa}$ and $58.3 \mathrm{MPa}$, respectively. This improvement was mainly due to the presence of nucleating ( $\mathrm{Al}, \mathrm{Ti}) \mathrm{B}_{2}$ and $\mathrm{Al}_{4} \mathrm{Sr}$ particles present in two different melts that were responsible for separate grain refinement and the modification effect. Use of the M05 master alloy alone on the Al-7Si alloy resulted in values of 58.3 $\mathrm{MPa}, 157.3 \mathrm{MPa}$ and $11.0 \%$ for $0.2 \%$ proof stress, UTS and $\%$ el, respectively, which were higher than with the addition of B-rich master alloys, which shows that the modification effect has more influence on mechanical properties than grain refinement. In other words, ductility of the Al-7Si alloy was increased by the addition of a modifier, which converted the needle particles of Si into fine fibrous form. A new combination of grain refiner cum modifier on the Al-7Si alloy resulted in further improvements in the mechanical properties. Improvements in mechanical properties in terms of percentage for both the Al-7Si alloy and the Al-11Si alloy are shown in Table 8 . It is clear from Table 8 that the addition of

Table 8. Percentage of improvement in mechanical properties of Al-7Si and Al-11Si alloys

\begin{tabular}{cccc}
\hline Alloy & $\begin{array}{c}0.2 \% \text { Proof } \\
\text { Stress }\end{array}$ & UTS (MPa) & $\%$ E \\
\hline Al-7Si & - & - & - \\
Al-7Si + 0.55\%M04 & 08.49 & 06.89 & 31.25 \\
Al-7Si + 0.20\% M05 & 10.00 & 08.48 & 37.50 \\
Al-7Si + 0.55\% M09 & 16.98 & 10.34 & 62.50 \\
Al-11Si & - & - & - \\
Al-11Si + 0.65\% M04 & 05.89 & 04.30 & 22.10 \\
Al-11Si + 0.30\% M05 & 12.96 & 18.55 & 35.78 \\
Al-11Si + 0.65\% M11 & 16.83 & 22.13 & 53.68 \\
\hline
\end{tabular}

$0.55 \mathrm{wt} \%$ of the M09 master alloy to the Al-7Si alloy resulted in an improvement of mechanical properties $(0.2 \%$ PS, UTS and \%el) to the extent of $17 \%, 10 \%$ and $62 \%$, respectively. Thus, the results of mechanical properties correlate with microstructural features and the use of an indigenously developed new combination of master alloys to obtain improved mechanical properties has been demonstrated.

\section{CONCLUSIONS}

Ternary Al-Ti-Sr, Al-B-Sr and quaternary Al-Ti-B-Sr master alloys were successfully prepared in the laboratory by the reaction of binary (Al-Ti and Al-B) and ternary (Al-Ti-B) master alloys with the Al-10Sr master alloy. The optimum addition level of a new combination of grain refiner cum modifiers was identified for the Al-7Si alloy using Al-Ti-Sr, $\mathrm{Al}-\mathrm{B}-\mathrm{Sr}$ and Al-Ti-B-Sr master alloys and for the Al-11Si alloy using Al-B-Sr and Al-Ti-B-Sr master alloys. The B-rich and Ti-containing (Al-1Ti-3B-3.6Sr) master alloy is more efficient than the Ti-rich and B-containing (Al-5Ti-1B-4.2Sr) master alloy for the combined grain refinement cum modification of the Al-7Si alloy. The B-rich and Ti-containing (Al1Ti-3B-4.6Sr) master alloy is more efficient than the B-containing (Al-3B-4.3Sr) master alloy for the combined grain refinement cum modification of the Al-11Si alloy. The presence of $\mathrm{Sr}$ does not influence grain refinement and similarly the presence of a grain refiner does not influence the modification of eutectic Si. The presence of newly formed $\mathrm{SrB}_{6}$ particles with the new combination of grain refiner cum modifier in $\mathrm{Al}-7 \mathrm{Si}$ and $\mathrm{Al}-11 \mathrm{Si}$ alloys exhibited better mechanical properties.

\section{ACKNOWLEDGMENTS}

The authors are grateful to the Department of Science and Technology, Ministry of HRD, Government of India, New Delhi for providing financial support to carry out this work. We are also thankful to Dr. R.N. Herkal, Principal, Basaveshwar Engineering College, Bagalkot for his kind permission to publish our work. 


\section{REFERENCES}

1. Y. S. Han, J. O. Choi, C. O. Choi, and D. G. McCartney, Met. Mater. Int. 10, 27 (2004).

2. J. E. Gruzleski and B. M. Closset, American Foundrymen's Society, 1 (1999).

3. S. A. Kori, Ph. D. Thesis, IIT Kharagpur, India (2000).

4. P. Feng, J. Tang, X. Jin, S. Li, and D. Zeng, Mater. Sci. Technol. 22, 50 (2006).

5. O. Uzun, F. Y1lmaz, U. Kolemen, and N. Basman, J. Alloys Compd. 509, 21 (2011).

6. S. A. Kori, B. S. Murty, and M. Chakraborty, Mater. Sci. Eng. A 283, 94 (2000).

7. K. G. Basavakumar, P. G. Mukunda, and M. Chakraborty, Mater. Characterization 59, 283 (2008).

8. M. Faraji and L. Katgerman, Inter. J. Cast Metals Research 22, 1 (2009).

9. Myunghan Kim, Met. Mater. Int. 13, 103 (2007).

10. L. Lu, A. K. Dahle, Mater. Sci. Eng. A 435-436, 288 (2006).

11. B. Suárez-Peña and J. Asensio-Lozano, Material Characterization 57, 218 (2006).

12. H. Liao, M. Zhang, Q. Wu, H. Wang, and G. Sun, Scr. Mater. 571121 (2007).

13. C. D. Mayes, D. G. McCartney, and G. J. Tatlock, Light Metals 1992, p.813, The Minerals Metals and Materials Society (1991).

14. D. G. McCartney, International Materials Reviews 34, 247 (1989).

15. K. Venkateswarlu, B. S. Murty, and M. Chakraborty, Mater. Sci. Eng. A 301, 180 (2001).
16. T. Wang, Z. Chen, H. Fu, J. Xu, Y. Fu, and T. Li, Scr. Mater. 64, 1121 (2011).

17. G. P. Jones and J. Pearson, Metall. Trans. B 7, 223 (1976).

18. P. S. Mohanty and J. E. Gruzleski, Acta Mater. 44, 3749 (1996).

19. B. S. Murty, S. A. Kori, and M. Chakraborty, International Materials Reviews 47, 3 (2002).

20. P. Moldovan, G. Popescu, C.A. Popescu, I. Apostolescu, and A. Buzaianu, Advanced Materials Research 23, 295 (2007).

21. N. E. Mahallawy, M. A. Taha, A. E. W. Jarfors, and H. Fredrikson, J. Alloys Compd. 292, 221 (1999).

22. X. Wang, R. Brydson, A. Jha, and J. Ellis, Journal of Microscopy 196, 137 (1999).

23. J. Fjellstedt, A. E. W. Jarfors, and L. Svendsen, J. Alloys Compds 283, 192 (1999).

24. A. J. Cornish, Met. Sci. Heat Treatment 19, 477 (1975).

25. R. Kiusalaas, Chemical Communications No. 1, University of Stockholm (1986).

26. J. A. Marcantonio and L. F. Mondolfo, Metall. Trans. B 7, 2, 465 (1971).

27. P. Li, E. G. Kandalova, and V. I. Nikitin, Mater. Lett. 59, 723 (2005).

28. L. Arnberg and L. Backeraud, H. Klang, Metals Technol. 9 , 1 (1982).

29. P. Schaffer and A. K. Dahle, Mater. Sci. Eng. A, 413-414, 373 (2005).

30. P. D. Sequeira, Y. Watanabe, and L. A. Rocha, Solid State Phenomena 105, 415 (2005). 